\title{
UWARUNKOWANIA WYSTĘPOWANIA ZABURZEŃ FUNKCJI POZNAWCZYCH U PACJENTÓW W WIEKU GERIATRYCZNYM HOSPITALIZOWANYCH NA ODDZIALE CHORÓB WEWNĘTRZNYCH
}

\section{DETERMINANTS OF COGNITIVE DISORDERS IN ELDERLY PATIENTS HOSPITALISED AT AN INTERNAL MEDICINE WARD}

\author{
Maria Kózka', Ewelina Gibadło ${ }^{2}$, Marlena Padykuła ${ }^{1}$ \\ ${ }^{1}$ Zakład Pielęgniarstwa Klinicznego, Instytut Pielęgniarstwa i Położnictwa, \\ Wydział Nauk o Zdrowiu, Uniwersytet Jagielloński - Collegium Medicum \\ ${ }^{2}$ absolwentka studiów drugiego stopnia, Wydział Nauk o Zdrowiu \\ Uniwersytet Jagielloński - Collegium Medicum; Oddział Kliniczny Chorób Serca i Naczyń \\ z Pododdziałem Intensywnego Nadzoru Kardiologicznego \\ Krakowski Szpital Specjalistyczny im. Jana Pawła II
}

DOI: https://doi.org/10.20883/pielpol.2018.34

\section{STRESZCZENIE}

Wstęp. Zaburzenia funkcji poznawczych są częstym problemem osób starszych. Poznanie uwarunkowań występowania zaburzeń poznawczych u osób starszych może mieć istotne znaczenie w zapewnieniu im optymalnej opieki podczas hospitalizacji.

Cel. Cele badań to ocena wpływu hospitalizacji na funkcje poznawcze pacjentów w starszym wieku oraz poznanie uwarunkowań występowania zaburzeń funkcji poznawczych u pacjentów w wieku geriatrycznym hospitalizowanych na oddziale chorób wewnętrznych.

Materiał i metody. Badaniem objęto 60 pacjentów w wieku powyżej 65 lat. Do zebrania danych zastosowano Test Upośledzenia Funkcji Poznawczych (MMSE), Skalę Aktywności Dnia Codziennego (ADL), Skalę Czynności Złożonych (IADL), Geriatryczną Skalę Oceny Depresji (GDS), Skalę Wsparcia Społecznego SSL12-I oraz kwestionariusz autorski.

Wyniki. Badania wykazały występowanie zaburzeń funkcji poznawczych o różnym nasileniu u pacjentów zarówno przy przyjęciu $(53 \%)$ na oddziały jak i przy wypisie (48\%) z oddziału. Analiza statystyczna nie wykazała zmian funkcji poznawczych w czasie pobytu w szpitalu $(p=0,482)$. Zaburzenia funkcji poznawczych występowały u badanych częściej wraz z obniżoną sprawnością funkcjonalną $(p<0,001)$, dłuższym czasem hospitalizacij $(p<0,05)$, obniżonym wsparciem społecznym (wsparcie w życiu codziennym $p=0,03$; wymiar dawania wsparcia $p=0,012$ ) i nasileniem objawów depresii (przy przyjęciu $p=0,03$; przy wypisie $p<0,01$ ). Wykazano, że poziom funkcjonowania poznawczego obniża się wraz z wiekiem badanego $(p<0,001)$ i jest istotnie niższy u badanych $z$ wykształceniem zawodowym $(p=0,022)$, owdowiałych $(p=0,003)$ i zamieszkujących wieś (przy przyjęciu $p=0,011$; przy wypisie $p=0,002$ ).

Wnioski. Zaburzenia funkcji poznawczych o różnym nasileniu przy przyjęciu i przy wypisie występowały u połowy badanych. Poziom funkcjonowania poznawczego w czasie pobytu w szpitalu nie uległ znaczącej zmianie u większości chorych. Występowanie zaburzeń poznawczych u osób starszych jest uwarunkowane

\section{ABSTRACT}

Introduction. Cognitive impairment is a common problem for the elderly. Thus, recognizing conditions for the occurrence of cognitive impairment in elderly patients may be vital in ensuring they receive optimal care during hospitalization.

Aim. The aim of study was to evaluate the influence of hospitalization on the cognition of elderly patients, and recognize the conditions for the occurrence of cognitive impairment in geriatric patients hospitalized at the Internal Medicine Ward.

Material and method. The study included 60 patients above 65 years of age. Mini-mental State Examination (MMSE), Activities of Daily Living (ADL) Scale, Instrumental Activities of Daily Living (IADL) Scale, Geriatric Depression Scale (GDS), SSL 12-I Social Support List, and an original questionnaire were used to collect data.

Results. The study showed occurrence of cognitive impairment with different levels of intensity both upon admission (53\%) and discharge (48\%) from the ward. Statistical analysis did not show a change in cognition during hospitalization ( $p=0.482$ ). Cognitive impairment occurred in patients more often when their functional performance decreased $(p<0.001)$, the period of hospitalization was longer $(p<0.05)$, social support was lower (support in daily life $p=0.03$; support provision $p=0.012$ ), and depression symptoms worsened (upon admission $p=0.03$; upon discharge $p<0.01$ ). It was showed that cognition lowered with patient's age $(p<0.001)$, and was significantly lower in patients who completed vocational education ( $p=0.022)$, became widowed ( $p=0.003)$, and lived in the countryside (upon admission $p=0.011$; upon discharge $p=0.002$ ).

Conclusions. Cognitive impairment with different levels of intensity occurred in a half of patients upon admission and discharge. The level of cognition during hospitalization did not change significantly in majority of patients. The occurrence of cognitive impairment in the elderly is conditioned by sociodemographic factors, the level of functional performance, the period of hospitalization, the level of social support, and occurrence of depression. 
zmiennymi socjodemograficznymi, poziomem sprawności funkcjonalnej, czasem hospitalizacji, poziomem wsparcia społecznego i występowaniem depresji. Całościowa ocena geriatryczna jest ważna dla zapewnienia jakości opieki nad pacjentem w wieku podeszłym.

SŁOWA KLUCZOWE: zaburzenia funkcji poznawczych, pacjent geriatryczny, hospitalizacja.

\section{Wstęp}

Problem starzenia się społeczeństwa dotyczy obecnie nie tylko Polski, lecz wszystkich państw świata. Prognozy demograficzne wskazują, że w ciągu najbliższych dziesięcioleci starzenie się społeczeństw utrzyma swój postępujący charakter, co przyczyni się do znacznego wzrostu liczby osób w wieku podeszłym [1]. Konsekwencją starzenia się jest wzrost procentowy udziału osób starszych wśród pacjentów hospitalizowanych na oddziałach zachowawczych [2]. Na podstawie danych Śląskiego Centrum Zdrowia Publicznego ocenia się, że liczba chorych po 65. roku życia zgłaszających się do lekarza będzie systematycznie wzrastać i pod koniec 2020 roku stanowić oni będą co najmniej 50\% pacjentów [3]. Starzenie się organizmu człowieka jest okresem, w którym stopniowemu pogorszeniu ulegają funkcje wszystkich układów i narządów, w tym także funkcje poznawcze [4-6].

Funkcjami poznawczymi nazywamy procesy określające zdolność mózgu do pozyskiwania informacji, przetwarzania ich i posługiwania się nimi. Funkcje poznawcze umożliwiają uczenie się, interpretacje rzeczywistości, są podstawą działania człowieka. Na funkcjonowanie poznawcze człowieka składa się szereg procesów intelektualnych tj.: pamięć krótkoterminowa oraz długoterminowa, procesy językowe (czytanie, pisanie, mowa), myślenie abstrakcyjne, funkcje wzrokowo-przestrzenne, konstrukcyjne i wykonawcze, procesy spostrzegania i percepcji bodźców ze środowiska zewnętrznego [4-7]. Do zaburzeń funkcji poznawczych należą łagodne zaburzenia funkcji poznawczych (ang. mild cognitive impairment - MCl) oraz otępienie [4, 5].

Zaburzenia w obrębie funkcjonowania poznawczego mają zasadniczy wpływ na życie codzienne osób starszych. Negatywnie wpływają na jakość życia zarówno ich samych, jak ich rodzinę oraz inne osoby sprawujące nad nimi opiekę [4-6].

U osób starszych hospitalizacja z powodu zaostrzeń choroby lub stanów zagrażających życiu powoduje obniżenie sprawności funkcji poznawczych, szczególnie osłabienie procesów uwagi, szybkości przetwarzania informacji, pamięci świeżej, pamięci operacyjnej i funk-
KEYWORDS: cognitive impairment, geriatric patient, hospitalization.

cji wykonawczych. Za pogorszenie sprawności umysłowej mogą odpowiadać układowe zapalenie, hipoksemia, hipotensja, dysregulacja gospodarki glukozą, zaburzenia wodno-elektrolitowe, zastosowanie leków przeciwbólowych, uspokajających, przebyty zabieg operacyjny [8, 9]. Dodatkowymi czynnikami związanymi z hospitalizacją mającymi wpływ na upośledzenie funkcji poznawczych są zmiana miejsca pobytu ze znanego otoczenia na nieznany, brak samodzielności w zakresie samoopieki spowodowany chorobą, ból, zaburzenia snu, liczne procedury diagnostyczne i lecznicze [10].

\section{Cel pracy}

Cele pracy to ocena wpływu hospitalizacji na funkcje poznawcze pacjentów w starszym wieku oraz poznanie uwarunkowań występowania zaburzeń funkcji poznawczych u pacjentów w wieku geriatrycznym hospitalizowanych na oddziale chorób wewnętrznych.

\section{Materiał i metody}

Badaniem objęto 60 pacjentów hospitalizowanych w Szpitalu Specjalistycznym im. Józefa Dietla w Krakowie na Oddziale Chorób Wewnętrznych. Do badań włączono osoby, które ukończyły 65 lat, przebywały na oddziale co najmniej 7 dni, wyraziły zgodę na udział w badaniach i były zdolne do wypełnienia narzędzi badawczych. Kryterium wyłączenia z badań stanowito rozpoznanie zespołu otępiennego odnotowanego w dokumentacji medycznej pacjenta. Do zebrania danych wykorzystano Krótką Skalę Oceny Stanu Umysłowego (MMSE), Skalę Aktywności Dnia Codziennego (ADL), Skalę Czynności Złożonych (IADL), Geriatryczną Skalę Oceny Depresji według Yesavage’a (GDS), Skalę Wsparcia Społecznego dla osób starszych (SSL12-I) oraz kwestionariusz autorski dotyczący danych socjodemograficznych, czasu pobytu i trybu przyjęcia do szpitala. Badanie skalą MMSE było przeprowadzane dwukrotnie: w pierwszym i w ostatnim dniu hospitalizacji.

W badaniu wzięło udział 36 kobiet (60\%) i 24 mężczyzn (40\%). Średni wiek badanych wynosił 77,18 roku $(\mathrm{SD}=7,67)$ i wahał się od 65 do 95 lat. Najliczniejszą grupe stanowiły osoby w przedziale wiekowym 65-70 
lat i 80-85 lat, natomiast najmniej liczną grupę stanowiły osoby w wieku 90-95 lat. Wykształcenie badanych było zróżnicowane, przeważały osoby z wykształceniem średnim (30\%). Zdecydowana większość badanych $(83 \%)$ była na emeryturze. Najwięcej spośród badanych stanowiły osoby owdowiałe (45\%), w związku małżeńskim pozostawało 33\% badanych. Ponad połowa badanych mieszkała w mieście (62\%). Największa grupa badanych (37\%) mieszkała z dziećmi, 35\% mieszkało samotnie, $22 \%$ badanych to osoby mieszkające ze współmałżonkiem bez dzieci, natomiast najmniej osób (6\%) mieszkało ze współmałżonkiem i z dziećmi. Przeważająca liczba badanych (68\%) cierpiała na trzy schorzenia lub więcej schorzeń, $23 \%$ spośród badanych cierpiało na dwa schorzenia, $9 \%$ - na jedno schorzenie. W trybie nagłym zostało przyjętych do szpitala $58 \%$ badanych. Średni czas pobytu pacjenta w szpitalu wynosił 10,93 dnia (SD = 3,98) i wahał się od 7 do 22 dni.

Obliczenia statystyczne wykonano za pomocą pakietu statystycznego R 3.1.3., przyjmując poziom istotności $<0,05$. Normalność rozkładu badanej zmiennej w obydwu grupach sprawdzono, korzystając z testu Shapiro-Wilka. W przypadku rozkładów normalnych różnice pomiędzy grupami analizowano za pomocą testu t-Studenta lub analizy wariancji ANOVA. W przypadku gdy rozkłady nie są normalne, różnice pomiędzy grupami analizowano za pomocą testu Manna-Whitneya lub Kruskala-Wallisa. Porównanie wyników przy przyjęciu i przy wypisie wykonano testem t-Studenta dla par wiązanych. Do oceny korelacji pomiędzy dwiema zmiennymi ilościowymi zastosowano współczynnik korelacji Pearsona lub Spearmana.

Na przeprowadzenie badań uzyskano zgodę Komisji Bioetycznej Uniwersytetu Jagiellońskiego (Nr KBET/224/B/2014 z dnia 25 września 2014 roku).

\section{Wyniki}

Przy przyjęciu na oddział zaburzenia funkcji poznawczych stwierdzono u ponad połowy badanych (53\%), w tym zaburzenia poznawcze bez otępienia u $27 \%$, otępienie lekkiego stopnia u $15 \%$ i otępienie średniego stopnia u 11\% badanych (Rycina 1). W dniu wypisu zaburzenia funkcji poznawczych stwierdzono u $48 \%$ badanych, w tym zaburzenia poznawcze bez otępienia u $23 \%$ badanych, otępienie lekkiego stopnia u $13 \%$ i otępienie średniego stopnia u 12\% (Rycina 2). Analiza statystyczna wyników uzyskanych przez badanych w skali MMSE w dniu przyjęcia i w dniu wypisu nie wykazała istotności statystycznej $(p=0,482)$, co oznacza, że funkcjonowanie poznawcze w czasie hospitalizacji nie uległo zmianie.

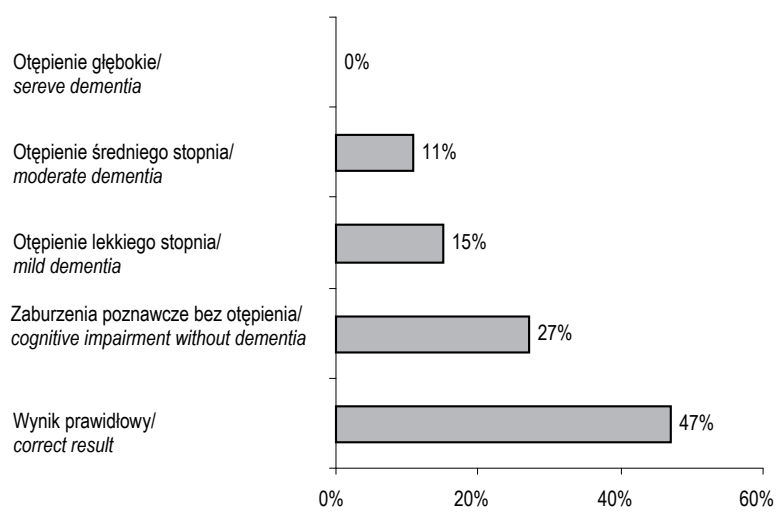

Rycina 1. Wyniki skali MMSE przy przyjęciu Figure 1. MMSE results upon admission

Źródło: opracowanie własne

Source: author's own analysis

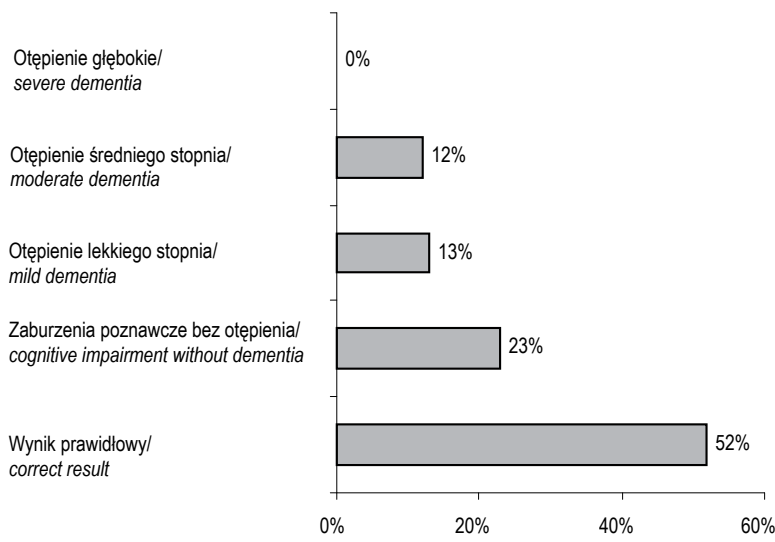

Rycina 2. Wyniki skali MMSE przy wypisie Figure 2. MMSE results upon discharge

Źródło: opracowanie własne

Source: author's own analysis

Analiza statystyczna pomiędzy danymi socjodemograficznymi a wynikami skali MMSE wykazała zależność kilku zmiennych (m.in. wieku, poziomu wykształcenia, miejsca zamieszkania, stanu cywilnego i zamieszkania) z występowaniem zaburzeń funkcji poznawczych. Badania wykazały, że wiek wpływa istotnie na wyniki osiągane w skali MMSE ( $p<0,001)$. Oznacza to, że z wiekiem częstość występowania zaburzeń poznawczych wzrasta. Wyniki pokazują, że badani z wykształceniem zawodowym osiągali niższe wyniki w skali MMSE niż pacjenci z wykształceniem wyższym. Badani mieszkający w mieście osiągali wyższe wyniki w skali MMSE oraz rzadziej u nich występowały zaburzenia poznawcze niż w grupie badanych mieszkających na wsi. Porównując wyniki MMSE w zależności od stanu cywilnego i zamieszkania badanych wykazano, że wyższe wyniki i wyższy poziom funkcjonowania poznawczego uzyskali badani będący w związku małżeńskim, a tak- 
że mieszkający samotnie lub w małżeństwie bez dzieci. Nie stwierdzono natomiast związku pomiędzy poziomem funkcjonowania poznawczego a płcią, źródłem utrzymania oraz trybem przyjęcia do szpitala. Zależności przedstawiono w tabeli 1.

Tabela 1. Zależności pomiędzy wynikami skali MMSE a danymi socjodemograficznymi badanych

Table 1. Relationships between MMSE results and sociodemographic data of the examined patients

\begin{tabular}{|c|c|c|c|c|c|c|c|}
\hline MMSE & $\begin{array}{l}\text { Zmienna/ } \\
\text { Variable }\end{array}$ & $\begin{array}{l}\text { Średnia/ } \\
\text { Average }\end{array}$ & SD & $\begin{array}{c}\text { Mediana/ } \\
\text { Median }\end{array}$ & $\begin{array}{l}\text { Min/ } \\
\text { Min }\end{array}$ & $\begin{array}{l}\text { Maks/ } \\
\text { Max }\end{array}$ & $p$ \\
\hline $\begin{array}{c}\text { Przy } \\
\text { przyjęciu/ } \\
\text { On admis- } \\
\text { sion }\end{array}$ & $\begin{array}{l}\text { Kobiety/ } \\
\text { Women } \\
\text { Mężczyźni/ } \\
\text { Men }\end{array}$ & $\begin{array}{l}25,08 \\
24,75\end{array}$ & $\begin{array}{l}4,25 \\
4,37\end{array}$ & $\begin{array}{l}26 \\
26\end{array}$ & $\begin{array}{l}12 \\
15\end{array}$ & $\begin{array}{l}30 \\
30\end{array}$ & 0,867 \\
\hline $\begin{array}{c}\text { Przy } \\
\text { wypisie/ } \\
\text { At discharge }\end{array}$ & $\begin{array}{l}\text { Kobiety/ } \\
\text { Women } \\
\text { Mężczyźni/ } \\
\text { Men }\end{array}$ & $\begin{array}{l}25,14 \\
24,29\end{array}$ & $\begin{array}{l}4,81 \\
5,35\end{array}$ & $\begin{array}{c}27 \\
26,5\end{array}$ & $\begin{array}{l}11 \\
12\end{array}$ & $\begin{array}{l}30 \\
30\end{array}$ & 0,564 \\
\hline $\begin{array}{c}\text { Przy } \\
\text { przyjęciu/ } \\
\text { On admis- } \\
\text { sion }\end{array}$ & $\begin{array}{c}\text { Podstawowe/ } \\
\text { Elementary } \\
\text { Zawodowe/ } \\
\text { vocational } \\
\text { Średnie/ } \\
\text { Secondary } \\
\text { Wyższe/ } \\
\text { Tertiary }\end{array}$ & $\begin{array}{l}22,85 \\
24,47 \\
25,89 \\
26,21\end{array}$ & $\begin{array}{l}4,65 \\
3,23 \\
3,39 \\
5,35\end{array}$ & $\begin{array}{l}22 \\
26 \\
27 \\
28\end{array}$ & $\begin{array}{l}16 \\
17 \\
15 \\
12\end{array}$ & $\begin{array}{l}30 \\
29 \\
30 \\
30\end{array}$ & 0,022 \\
\hline $\begin{array}{c}\text { Przy } \\
\text { wypisie/ } \\
\text { At discharge }\end{array}$ & $\begin{array}{c}\text { Podstawowe/ } \\
\text { Elementary } \\
\text { Zawodowe/ } \\
\text { Vocational } \\
\text { Średnie/ } \\
\text { Secondary } \\
\text { Wyższe/ } \\
\text { Tertiary }\end{array}$ & $\begin{array}{l}22,62 \\
23,67 \\
26,11 \\
26,36\end{array}$ & $\begin{array}{l}5,22 \\
5,01 \\
3,34 \\
5,97\end{array}$ & $\begin{array}{l}25 \\
25 \\
27 \\
29\end{array}$ & $\begin{array}{l}14 \\
12 \\
16 \\
11\end{array}$ & $\begin{array}{l}30 \\
29 \\
30 \\
30\end{array}$ & 0,02 \\
\hline $\begin{array}{c}\text { Przy } \\
\text { przyjęciu/ } \\
\text { On admis- } \\
\text { sion }\end{array}$ & $\begin{array}{l}\text { Miasto/City } \\
\text { Wieś/Village }\end{array}$ & $\begin{array}{l}25,76 \\
23,65\end{array}$ & $\begin{array}{l}4,37 \\
3,82\end{array}$ & $\begin{array}{l}27 \\
24\end{array}$ & $\begin{array}{l}12 \\
16\end{array}$ & $\begin{array}{l}30 \\
29\end{array}$ & 0,011 \\
\hline $\begin{array}{c}\text { Przy } \\
\text { wypisie/ } \\
\text { At discharge }\end{array}$ & $\begin{array}{l}\text { Miasto/City } \\
\text { Wieś/Village }\end{array}$ & $\begin{array}{c}25,7 \\
23,35\end{array}$ & $\begin{array}{l}5,02 \\
4,73\end{array}$ & $\begin{array}{l}28 \\
25\end{array}$ & $\begin{array}{l}11 \\
14\end{array}$ & $\begin{array}{l}30 \\
29\end{array}$ & 0,02 \\
\hline $\begin{array}{c}\text { Przy } \\
\text { przyjęciu/ } \\
\text { On admis- } \\
\text { sion }\end{array}$ & $\begin{array}{l}\text { Emerytura } \\
\text { lub renta/ } \\
\text { Pension or } \\
\text { disability } \\
\text { benefits } \\
\text { Emerytura } \\
\text { i praca/ } \\
\text { Pension and } \\
\text { disability } \\
\text { benefits }\end{array}$ & $\begin{array}{l}24,63 \\
26,78\end{array}$ & $\begin{array}{l}4,41 \\
2,86\end{array}$ & $\begin{array}{l}26 \\
27\end{array}$ & $\begin{array}{l}12 \\
22\end{array}$ & $\begin{array}{l}30 \\
30\end{array}$ & 0,186 \\
\hline $\begin{array}{c}\text { Przy } \\
\text { wypisie/ } \\
\text { At discharge }\end{array}$ & $\begin{array}{l}\text { Emerytura } \\
\text { lub renta/ } \\
\text { Pension } \\
\text { or disability } \\
\text { benefits } \\
\text { Emerytura } \\
\text { i praca/ } \\
\text { Pension and } \\
\text { disability } \\
\text { benefits }\end{array}$ & $\begin{array}{l}24,39 \\
27,11\end{array}$ & $\begin{array}{l}5,18 \\
3,14\end{array}$ & $\begin{array}{l}26 \\
28\end{array}$ & $\begin{array}{l}11 \\
21\end{array}$ & $\begin{array}{l}30 \\
30\end{array}$ & 0,097 \\
\hline
\end{tabular}

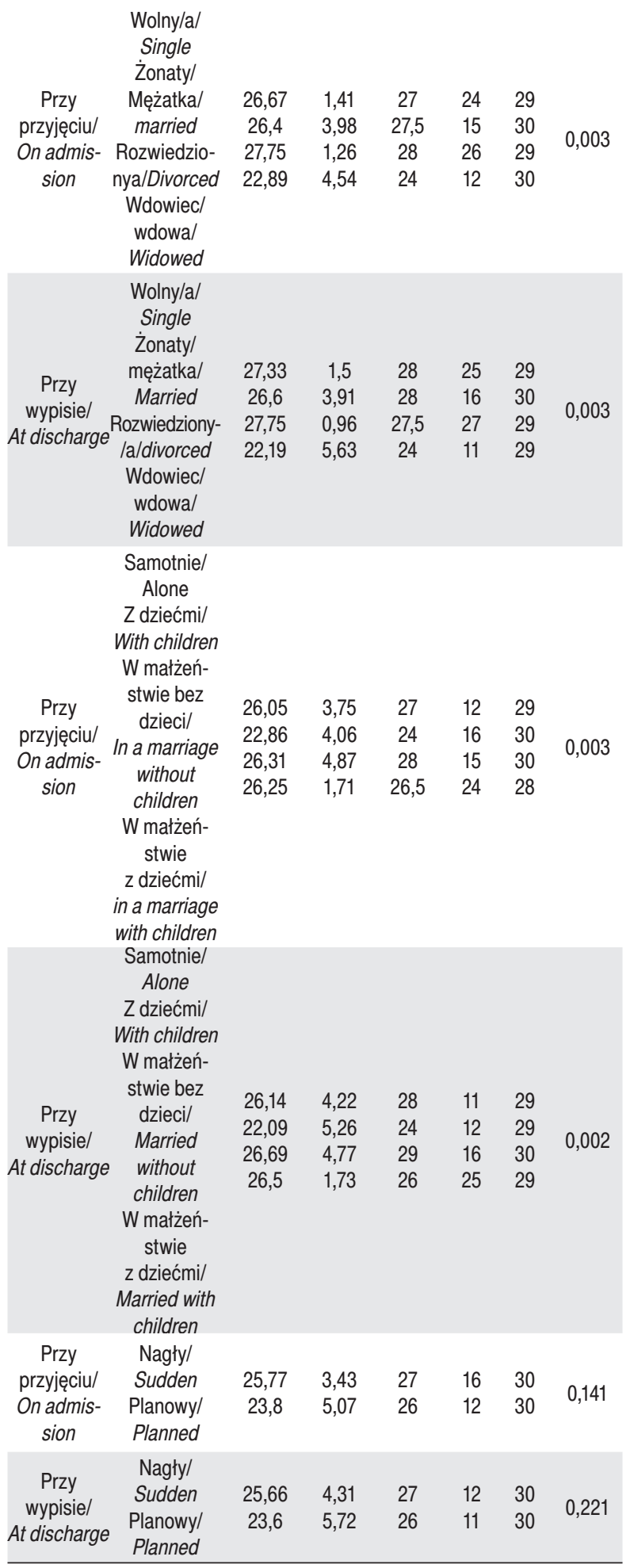

Źródło: opracowanie własne

Source: author's own analysis

Przeprowadzone analizy statystyczne wykazały istnienie dodatniej korelacji pomiędzy występowaniem zaburzeń funkcji poznawczych a sprawnością funkcjonalną badanych ocenioną wg skali ADL $(p<0,001)$ i IADL $(p<0,001)$. Analiza potwierdziła, że badani pre- 
zentujący lepszą sprawność funkcjonalną w zakresie podstawowych i złożonych czynności dnia codziennego rzadziej przejawiali zaburzenia funkcji poznawczych (wyższy wynik MMSE).

W przeprowadzonym badaniu oceniono zależność między stopniem wsparcia społecznego a występowaniem zaburzeń funkcji poznawczych u pacjentów geriatrycznych. Stwierdzono, że im wyższy wynik skali SSL-12I w wymiarze wsparcia w codziennym życiu oraz w wymiarze dawania wsparcia, tym wyższy wynik MMSE uzyskali badani przy wypisie ( $p=0,03 ; p=0,012)$. Oznacza to, że u badanych, którzy otrzymywali duże wsparcie w codziennym życiu oraz dawali duże wsparcie innym, rzadziej występowały zaburzenia poznawcze. Nie stwierdzono istnienia korelacji pomiędzy wynikami uzyskiwanymi przez badanych w skali SSL 12-I w wymiarze wsparcia w sytuacjach trudnych i skali MMSE.

Na podstawie analizy danych z przeprowadzonego badania potwierdzono występowanie istotnej statystycznie zależności między występowaniem objawów depresji a występowaniem zaburzeń funkcji poznawczych (przy przyjęciu $p=0,003$; przy wypisie $p<0,001$ ). Im większe nasilenie objawów depresji (wyższy wynik GDS), tym gorszy poziom funkcjonowania poznawczego (niższy wynik MMSE).

Z analizy badań wynika, że czas hospitalizacji koreluje z wynikiem MMSE przy przyjęciu i przy wypisie $(p<0,05)$. Badani, którzy dłużej przebywali w szpitalu, zdecydowanie częściej prezentowali zaburzenia funkcji kognitywnych. Zależność przedstawiono w tabeli 2.

Tabela 2. Zależność pomiędzy wynikami skali MMSE a długością hospitalizacji

Table 2. Relationships between MMSE results and lenght of hospitalization

\begin{tabular}{ccccc}
\hline & \multicolumn{3}{c}{$\begin{array}{c}\text { Korelacja z czasem hospitalizacij/ } \\
\text { Correlation with time of hospitalization }\end{array}$} \\
\cline { 2 - 5 } MMSE & $\begin{array}{c}\text { Współczynnik } \\
\text { korelacji/ } \\
\text { Correlation } \\
\text { coefficient }\end{array}$ & $p$ & $\begin{array}{c}\text { Kierunek } \\
\text { zależności/ } \\
\text { Direction of } \\
\text { dependence }\end{array}$ & $\begin{array}{c}\text { Siła } \\
\text { zależności/ } \\
\text { Strength } \\
\text { of dependence }\end{array}$ \\
\hline $\begin{array}{c}\text { Przy } \\
\text { przyjęciu/ }\end{array}$ & $-0,442$ & $<0,001$ & $\begin{array}{c}\text { ujemny/ } \\
\text { negative }\end{array}$ & $\begin{array}{c}\text { średnia/ } \\
\text { average }\end{array}$ \\
$\begin{array}{c}\text { On admission } \\
\text { Przy } \\
\text { wypisie/ }\end{array}$ & $-0,509$ & $<0,001$ & $\begin{array}{c}\text { ujemny/ } \\
\text { negative }\end{array}$ & silna/ \\
At discharge & & & & strong \\
\hline
\end{tabular}

Źródło: opracowanie własne

Source: author's own analysis

\section{Dyskusja}

Granica wieku podeszłego została określona jako ukończenie 65. roku życia. Okres starości charakteryzuje się odmiennym przebiegiem procesu starzenia dla każdej osoby, współwystępowaniem różnych chorób, wielolekowością. W grupie osób starszych często występują problemy o kilku podłożach równocześnie: organicznym, psychologicznym, społecznym i poznawczym [11-13]. Wczesne wykrycie zaburzeń z zakresu funkcjonowania poznawczego daje szansę na spowolnienie toczącego się procesu, dzięki czemu istnieje możliwość zachowania samodzielności pacjentów geriatrycznych [6].

W badaniach własnych wykazano występowanie zaburzeń poznawczych u 53\% badanych przy przyjeciu oraz $48 \%$ przy wypisie. Autorki w innych swoich badaniach uzyskały podobne wyniki - zaburzenia funkcji kognitywnych występowały u $69 \%$ badanych, w tym u $58 \%$ o charakterze łagodnym i u $11 \%$ o typie otępienia lekkiego stopnia [14]. W badaniach Treder i wsp. zaburzenia funkcji poznawczych w grupie 79 osób zdrowych występowały u 73\% badanych [15]. Przy wypisie więcej pacjentów uzyskało wynik prawidłowy, natomiast mniej pacjentów uzyskało wynik wskazujący na zaburzenia poznawcze bez otępienia oraz otępienie lekkiego stopnia. Może to sugerować, iż stan zdrowia przy przyjęciu i powód hospitalizacji wpływały na osiąganie niższych wyników w skali MMSE, a kompleksowa opieka i leczenie podczas hospitalizacji poprawiają w nieznacznym stopniu funkcjonowanie fizyczne i poznawcze. Analiza statystyczna jednak nie wykazała istotności statystycznej między wynikami przy przyjęciu i przy wypisie, tak więc poziom funkcjonowania poznawczego w czasie pobytu w szpitalu nie uległ znaczącej zmianie u większości chorych. Brak stwierdzenia tej zależności może wynikać z faktu, że respondenci stanowili małą grupę. Zasadne wydaje się przeprowadzenie badań wśród większej liczby pacjentów.

W ramach przeprowadzonych badań wykonano analizę zależności między występowaniem zaburzeń funkcji poznawczych a czasem hospitalizacji. Wykazano, że czas hospitalizacji istotnie statystycznie koreluje z funkcjami kognitywnymi, tzn. im dłuższy czas hospitalizacji, tym gorsza sprawność poznawcza. Wyniki te potwierdzają przeprowadzone przez Wilsona i wsp. badania, w których autorzy wykazali, że dłuższy pobyt w szpitalu wiązał się ze spadkiem zdolności poznawczych w porównaniu z czasem sprzed hospitalizacji [16].

Badania własne wykazały silny związek pomiędzy wiekiem a występowaniem zaburzeń poznawczych. Wraz z wiekiem zwiększała się częstość występowania zaburzeń kognitywnych. W badaniach przeprowadzonych przez Pniewską i wsp. wykazano związek między wiekiem pacjenta a wynikami testów do oceny funkcjonowania poznawczego - im starszy wiek badanych, tym gorsze funkcjonowanie poznawcze [17]. Wyniki badań Tomaszewskiej i wsp. również potwierdzają ten związek [18]. Proces starzenia związany jest z osłabieniem pro- 
cesów pamięciowych, spowolnieniem przetwarzania informacji, zmniejszoną uwagą, utrudnieniem wykonywania zadań celowych [4].

$\mathrm{W}$ badaniach własnych zaobserwowano istnienie zależności pomiędzy miejscem zamieszkania a występowaniem zaburzeń funkcji poznawczych. Zaburzenia funkcji kognitywnych częściej występowały u osób mieszkających na wsi. Badania przeprowadzone przez Kurzawę i wsp. wykazały, że u osób mieszkających w środowisku wiejskim upośledzenie funkcji poznawczych występuje częściej [19]. Zależność potwierdzają również badania Kowalskiej i wsp., - osoby mieszkające w mieście osiągały więcej punktów w skali MMSE w porównaniu do osób zamieszkujących wieś [20]. Może to wynikać z faktu, iż osoby zamieszkujące wieś częściej deklarują wykształcenie niższe i średnie oraz mniej czasu poświęcają na rehabilitację procesów poznawczych niż mieszkańcy miast. Analizując uzyskane wyniki, stwierdzono, że z występowaniem zaburzeń w zakresie funkcjonowania poznawczego koreluje poziom wykształcenia. Zarówno przy przyjęciu, jak i przy wypisie zaburzenia otępienne częściej występowały u osób z niższym wykształceniem. Podobną zależność wykazały Kurzawa [19] oraz Pniewska [17].

W badaniach własnych analiza statystyczna nie wykazała związku pomiędzy zaburzeniami funkcji poznawczych a płcią. Odmienne wyniki uzyskali w swych badaniach Paúl i wsp., którzy wykazali, że upośledzenie funkcji poznawczych jest wyższe u kobiet [21]. Podobną zależność uzyskali Bidzan i wsp. Ich badania wykazały większączęstość występowaniazaburzeńotępiennych wśród kobiet [22]. Brak stwierdzenia zależności między płcią a występowaniem zaburzeń poznawczych w badaniach własnych może wynikać z faktu, że respondenci stanowili małą grupę.

Czynnikiem, który wykazuje zależność z poziomem funkcjonowania poznawczego jest sprawność w zakresie podstawowych i złożonych czynności dnia codziennego. Badania własne wykazały, że osoby samodzielne w zakresie podstawowych i złożonych czynności dnia codziennego rzadziej przejawiają zaburzenia poznawcze. Związek stanu funkcjonalnego z zaburzeniami funkcji poznawczych potwierdzają w swych badaniach Sauvaget [23], Kowalska [20] oraz Rogers i Jarrot [24].

Kolejnym czynnikiem pogarszającym aktywność poznawczą osób starszych jest poziom wsparcia społecznego. Analiza badań własnych wykazała, że zaburzenia funkcji kognitywnych występowały rzadziej u osób osiągających wyższy poziom wsparcia w codziennym życiu oraz lepiej oceniający własną wartość jako dawcy wsparcia. Natomiast poziom wsparcia w sytuacjach trudnych nie wpływał istotnie statystycznie na funkcjonowanie poznawcze. Zależność potwierdzają badania
Shu-Chuan i Yea-Ying. Wyniki ich badań dowiodły, że osoby, które odczuwały wysoki poziom wsparcia ze strony otoczenia, prezentowały wyższy poziom w zakresie funkcji kognitywnych niż osoby, które nie odczuwały wsparcia [25]. U osób w starszym wieku otrzymywanie wsparcia w codziennym życiu oraz dawanie wsparcia innym wydaje się bardzo ważne, umacnia więzi rodzinne i społeczne, wzmacnia poczucie własnej wartości, wpływa na samoocenę i jakość życia [14].

Współwystępowanie zaburzeń kognitywnych i depresyjnych jest częstym problemem u ludzi w podeszłym wieku - powoduje pogorszenie jakości życia, codziennego funkcjonowania, przebiegu współwystępujących chorób somatycznych, zwiększenie śmiertelności. Różnicowanie tych zaburzeń jest trudne, gdyż z jednej strony zaburzenia funkcji poznawczych mogą dominować w obrazie depresji, a z drugiej strony objawy depresji mogą przykrywać zaburzenia poznawcze [26]. Związek objawów depresyjnych ze sprawnością w zakresie funkcji kognitywnych podkreśla wielu autorów. W wyniku analizy statystycznej badań własnych potwierdzono powyższe zależności - zaburzenia poznawcze częściej występowały u osób z objawami depresyjnymi (wyniki skali GDS). Badania Puto, Ocetkiewicza i Zawiszy oceniające wpływ objawów depresji i funkcji poznawczych na subiektywną ocenę jakości życia pacjentów po 80. roku życia wykazały, że nasilenie objawów depresji powodowało wzrost upośledzenia funkcjonowania poznawczego [27].

Starzenie się organizmu wpływa na wszystkie układy, również na układ nerwowy, i na procesy poznawcze. Tempo oraz stopień zaburzeń funkcji poznawczych występujących u osób starszych zależy od wielu czynników, m.in. diety [28, 29], odczuwanego bólu [30], stosowanego leczenia przeciwbólowego, szczególnie dotyczy to morfiny i tramadolu [31, 32], występujących zaburzeń wodnoelektrolitowych, niedociśnienia, hipoksemii $[8,28]$.

\section{Wnioski}

1. Połowa badanych miała zaburzenia funkcji poznawczych o różnym nasileniu przy przyjęciu i przy wypisie.

2. Poziom funkcjonowania poznawczego w czasie pobytu w szpitalu nie uległ znaczącej zmianie u większości chorych. Przy wypisie więcej pacjentów uzyskało wynik prawidłowy, natomiast mniej pacjentów uzyskało wynik wskazujący na zaburzenia poznawcze bez otępienia oraz otępienie lekkiego stopnia.

3. Czas hospitalizacji istotnie koreluje z poziomem funkcjonowania poznawczego. Dłuższy czas hospitalizacji wpływa negatywnie na sprawność funkcji poznawczych. 
4. Wykazano istotną statystycznie zależność pomiędzy występowaniem zaburzeń funkcji poznawczych a danymi socjodemograficznymi (m.in. wiekiem, poziomem wykształcenia, miejscem zamieszkania, stanem cywilnym), stopniem sprawności funkcjonalnej, występowaniem objawów depresji oraz poziomem wsparcia społecznego w zakresie wsparcia w życiu codziennym oraz oceny własnej wartości jako dawcy wsparcia.

\section{Piśmiennictwo}

1. Ostryżek A. Ocena jakości życia osób w podeszłym wieku rehabilitowanych w oddziale opieki długoterminowej. Probl Hig Epidemiol. 2010; 4: 659-666.

2. Szmytkowska I, Doboszyńska A, Serafiński J, Cezak A. Przyczyny hospitalizacji chorych z zaburzeniami gospodarki węglowodanowej (ZGW). Geriatria Pol. 2005; 1: 12-17.

3. Majer R, Pietrzak J, Rejdak M et al. Hospitalizacja - wiek podeszły. Katowice: Śląskie Centrum Zdrowia Publicznego; 2007.

4. Kowalska J, Szczepańska-Gieracha J, Rymaszewska J. Zaburzenia funkcji poznawczych i zespoły otępienne - problem fizjoterapii geriatrycznej. Fizjoterapia. 2010; 18(2): 73-80.

5. Kolan M. Zaburzenia funkcji poznawczych a choroby niedokrwienne mózgu. W: Nowakowski P (red.). Neurokognitywistyka w patologii i zdrowiu. Szczecin: PUM; 2009-2011.

6. Derkacz M, Chmiel-Perzyńska I, Kowal A. TYM TEST - nowe narzędzie diagnostyczne w ocenie funkcji poznawczych badanie mieszkańców opieki społecznej. Curr Probl Psychiatry. 2011; 12(2): 152-159.

7. Talarowska M, Florkowski A, Macander M, Gałecki P. Grypa i infekcje grypopochodne a funkcje poznawcze. Neuropsychiatr Neuropsychol. 2010; 5, 3-4: 149-154.

8. Ehlenbach WJ, Hough CL, Crane PK et al. Association between acute care and critical illness hospitalization and cognitive function in older adults. JAMA. 2010; 303(8): 763-770.

9. Otremba I. Czynniki predysponujące do rozwinięcia się zespołu majaczeniowego u chorych hospitalizowanych na oddziale geriatrycznym. Probl Piel. 2015; 23(1): 46-50.

10. Bidzan L. Otępienie czołowo-skroniowe. Problemy diagnostyczne i terapeutyczne. Geriatria. 2012; 6: 41-45.

11. Tobis $S$ et al. Wieloprofesjonalność opieki w geriatrii. Now Lek. 2013; 1: 51-55.

12. Wieczorowska-Tobis K. Specyfika pacjenta starszego. W: Wieczorowska-Tobis K, Kostka T, Borowicz AM. Fizjoterapia w geriatrii. Warszawa: PZWL; 2011. 18-27.

13. Jajor J et al. Specyfika rehabilitacji ruchowej osób starszych. Now Lek. 2013; 1: 89-96.

14. Padykuła M, Kózka M. Zaburzenia funkcji poznawczych u pacjentów w wieku geriatrycznym hospitalizowanych na oddziale zachowawczym. Probl Piel. 2015; 23(3): 300-305.

15. Woźniak J et al. Ocena sprawności ogólnej, funkcjonowania codziennego oraz jakości życia u chorych w podeszłym wieku z podejrzeniem zespołu otępiennego. Psychogeriatr Pol. 2012; 9(4): 149-160.

16. Wilson RS, Hebert LE, Scherr PA, Dong X, Leurgens SE, Evans DA. Cognitive decline after hospitalization in a community population of older persons. Neurology. 2012; 78(13): 950-956.

17. Pniewska $\mathrm{J}$ et al. Styl życia a funkcjonowanie poznawcze osób starszych. Doniesienie wstępne. Now Lek. 2012; 81 (1): 10-15.
18. Tomaszewska M et al. Test Stroopa - wartość diagnostyczna w psychiatrii. Neuropsychiatr Neuropsychol. 2010; 1: 35-41.

19. Kurzawa J, Zozulińska D, Wierusz-Wysocka B. Ocena występowania zaburzeń funkcji poznawczych u chorych na cukrzycę. Diabetol Prakt. 2004; 5

20. Kowalska J, Szczepańska-Gieracha J, Piątek J. Zaburzenia poznawcze i emocjonalne a długość pobytu osób starszych w Zakładzie Opiekuńczo-Leczniczym o Profilu Rehabilitacyjnym. Psychogeriatr Pol. 2010; 7.

21. Paúl $C$ et al. Cognitive impairment in old people living in the community. Arch Gerontol Geriatr. 2010; 51(2): 121-124.

22. Hausz-Piskorz B, Buczkowski K. Diagnostyka i leczenie choroby Alzheimera w warunkach praktyki lekarza rodzinnego. Forum Med Rodz. 2013; 4: 198-207.

23. Sauvaget $C$ et al. Dementia as a predictor of functional disability: a four-year follow-up study. Gerontology. 2002; 4: 226-233.

24. Rogers S, Jarrot S. Cognitive impairment and effects on upper body strength of adults with dementia. J Aging Physic Activity. 2008; 16: 61-68.

25. Shu-Chuan J, Yea-Ying L. Influence of social support on cognitive function in the elderly. BMC Health Services Research. 2003; 3: 9.

26. Zwyrtek E, Rymaszewska J. Różnicowanie zaburzeń otępiennych i depresyjnych u osób w podeszłym wieku. Lekarz POZ. 2016; 2(1): 30-36.

27. Puto G, Ocetkiewicz T, Zawisza T. Wpływ depresji i funkcji poznawczych na subiektywną ocenę jakości życia pacjentów z chorobą niedokrwienną serca po 80. roku życia. Gerontol Pol. 2007; 3: 90-96.

28. Pniewska J, Jaracz K, Górna K, Suwalska A. Czynniki protekcyjne funkcji poznawczych w procesie starzenia się - przegląd piśmiennictwa. Neuropsychiatr Neuropsychol. 2011; 6, 3-4: 166-171.

29. Kesse-Guyot E, Peanu S, Ferry M et al. Thirteen-year prospective study between fish concumption, long-chain n-3 fatty AIDS intakes and cognitive function. J Nutr Health Aging. 2011. 15: 115-120.

30. Wieczorowska-Tobis K, Rajska-Neumann A. Ból jako przyczyna zaburzeń funkcji poznawczych u starszych pacjentów. Geriatria. 2010; 4: 292-294.

31. Modlińska A. Tramadol - metabolizm; wpływ na funkcje poznawcze. Psychoonkol. 2007; 12: 12-18.

32. Buss T. Wpływ morfiny na funkcje poznawcze u pacjentów z bólem przewlekłym. Psychoonkol. 2007; 12; 1: 19-23.

Artykuł przyjęty do redakcji: 03.10.2017.

Artykuł przyjęty do publikacji:15.06.218.

Źródło finansowania: Praca nie jest finansowana z żadnego źródła. Konflikt interesów: Autorzy deklarują brak konfliktu interesów.

Adres do korespondencji:
Marlena Padykuła
ul. Mikołaja Kopernika 25
31-005 Kraków
tel.: 124214160
e-mail: marlena.padykula@uj.edu.pl
Zakład Pielęgniarstwa Klinicznego, Instytut Pielęgniarstwa
i Położnictwa, Wydział Nauk o Zdrowiu,
Uniwersytet Jagielloński - Collegium Medicum

